\title{
1 DOES GENDER EXACERBATE THE EFFECT OF WORK-FAMILY CONFLICT ON EMPLOYEE SATISFACTION IN THE HOTEL INDUSTRY?
}

\author{
Eunice Fay Amissah ${ }^{1}$, Valerie Efua Kwansima Bempong ${ }^{1}$, Emmanuel Gamor ${ }^{2}$
}

\begin{abstract}
Hotel employees, in recent times, put in more effort at work, working for long hours and even on holidays and weekends. As a result, they find it difficult to efficiently meet the demands of both their work and personal life. This study used a cross-sectional research design to examine work-family conflict and its effects on job satisfaction and life satisfaction of hotel staff. The study also sought to examine the moderating effect of gender on the relationships between work-family conflict, job satisfaction and life satisfaction. A diverse sample of 286 respondents, conveniently selected, completed a structured questionnaire. Generally, the results of a PLS-SEM analysis showed that work-family conflict is not significantly related to job satisfaction but with employees' life satisfaction. Specifically, work-to-family conflict has no significant relationship with job satisfaction whereas work-to-family and family-to-work conflict were uniquely associated with life satisfaction. The interference of family demands with the work of a hotel employee positively affects life satisfaction irrespective of the gender of employees. However, job satisfaction significantly relates to life satisfaction. Gender fully moderated employee work interfering with family and job satisfaction relationship. Theoretical and practical implications as well as directions for future studies were discussed in the paper.
\end{abstract}

Key words: work-family conflict, job satisfaction, life satisfaction, gender, hotels

\section{INTRODUCTION}

Work and family are seen as essential parts of every adult life (Morrison, Mensah, Kpakpo \& Asante, 2020; Nordenmark, 2017). The responsibilities of work and family roles require resources. Nevertheless, the role scarcity hypothesis posits that individuals are constrained with scarce and limited resources including time. Therefore, it is difficult for employees to successfully juggle the demands that arise from the domains of work and family. Consequently, resulting in an inter-role conflict where the two roles would compete for the individual's resources, creating incompatibility that generates conflict between employees' work life, and family life (Laode, Nur, Taufik, Sabara, Rosmawaty, Kartini, \& Mirad, 2017). This inter-role conflict is known as work-family conflict [WFC] (Geurts, Taris, Kompier, Dikkers, Van Hooff \& Kinnunen, 2005).
Even though work-family conflict is a common issue encountered by the majority of employees (Aslam et al., 2011, Morrison et al., 2020), those in the hotel sector tend to experience it more since there are more demands on employees to make the sector competitive which may negatively impact performance (Sultan \& Akhtar, 2019; Weerasinghe \& Batagoda, 2015). Specifically, the hotel sector like any other service industry is known to be labour intensive, characterized by long work hours and irregular job patterns aimed at ensuring the satisfaction of guests. Employees work almost 24 hours, weekends and holidays making hotel jobs quite demanding. Meanwhile, individuals also owe their family certain duties and responsibilities such as household chores, parental, marital and care roles. Together, these make hotel employees vulnerable to work-family conflict. These make hotel employees

1. University of Cape Coast, Department of Hospitality and Tourism Management, Cape Coast, Ghana, Email: eamissah@ucc.edu.gh, valerie.bempong@stu.ucc.edu.gh

2. Hong Kong Polytechnic University, School of Hotel and Tourism Management, Kowloon, Hong Kong, Email: emmanuel.gamor@connect.polyu.hk 
mostly susceptible to inter-role conflict, particularly in luxury hotels where customer satisfaction remains a key requirement. Employees are therefore required to go the extra mile such as dealing with heavy workload, dealing with jay customers and working for longer hours which may affect their family roles. Subsequently, creating work-life conflict with its concomitant effect on employees' job performance and life.

The Spillover theory posits that emotions such as moods as well as stress, and the recurring thoughts generated in a role domain often have the potential of influencing or spilling over into other domains. This is usually detected in situations where some form of inter-role conflict exist. Such that involvement in work-role may reduce the effective performance of family role, and the reverse is true. Kalliath, Kalliath, and Singh (2011) posited that workers often carry their emotion, skills, behaviour, and attitude related to work to their families. Spillover can impact work-family relationship negatively and positively. For a positive spillover to arise, satisfaction in one domain together with achievements can lead to satisfaction and success in the other sphere. In the case of a negative spillover, dissatisfaction in one area leads to dissatisfaction in the other domain (Xiao \& O'Neill, 2010).

The concept of work-family conflict is a growing area of research that has attracted the interest of researchers in recent years. Particularly the examination of the effect of work-family conflict on various work outcomes of employees and the consequences on the individual (Zhang, Griffeth, \& Fried, 2012; Ru Hsu, 2011). Studies including that of Gamor, Amissah, Amissah, and Nartey (2018), Gamor, Amissah, and Boakye (2014), O'Neill and Davis (2011), and Xiao and O'Neill (2010) have explored WFC in the hotel sub-sector. Nevertheless, little attempt has been made to examine links between WFC, job and life satisfaction of employees in such settings. Although studies have been conducted individually on job satisfaction (Amissah, Gamor, Deri, \& Amissah, 2016; Goris, 2007) and work-family conflict (Turliuc \& Buliga, 2014; Gamor, Amissah, \& Boakye, 2014; Rathi \& Barath, 2013), little attention has been given to the relationships between these constructs in luxury hotels in Ghana (Mensah, Amissah, \& Nsaful, 2018; Segbenya \& Dela Ahiatrogah, 2018). Besides, there is a dearth of information regarding the relationships between the bi-directional nature of work-family conflict and hotel employees' gender (Ma \& Turel, 2019; Yoo \& Lee, 2018), especially from developing countries.

Through the spillover lens, this study examines the perceived effect that domain spillovers have on employees' satisfaction with job and life. Specifically, it examines the perceived effect of work and family demands on employees' job satisfaction and life satisfaction. The study also examines the moderating role of gender on the relationships existing between work-family conflict, and employees' job and life satisfaction. The results of this study add to the body of knowledge on WFC by bringing to fore the nature of the relationships in the context of an emerging economy. Secondly, it gives an insight into the relationship between WFC, job and life outcomes of employees.

\section{LITERATURE REVIEW}

\section{Work-Family Conflict}

Role conflicts between work and family were first elucidated by the study of Kahn, Wolfe, Quinn, Snoek and Rosenthal (1964). The conflict was further explained by Greenhaus and Beutell (1985) that demands from one role influence one's ability to successfully satisfy the requirements connected with other roles in the other domain. In view of this, workfamily conflict, as a concept, was defined as a form of inter-role conflict in which the role pressures from work and family domains are mutually incompatible 
in some respect (Greenhaus \& Beutell, 1985). Similarly, other researchers have acknowledged that demands from the workplace and that of the family are mutually incompatible (Higgins, Duxbury, \& Lyons, 2007). Hence, meeting the demands of these two domains successfully has become difficult.

The concept of work-family conflict suggests bi-directional effects facilitated by two main dimensions to the phenomenon. According to Aslam, Shumiala, Azhar, and Sadaqat, (2011) the concept of WFC is conceptualised as a construct that can affect work demands and, family demands. Whenever there is an assessment of the likelihood of an individual to experience inter-role conflict, the direction of the effect must be taken into consideration. The bidirectional characteristics of work-family conflict (Qiu \& Fan, 2015; Rathi \& Barath, 2013; Beutell, 2010; Kinnunen, Feldt, Mauno, \& Rantanen, 2010) shows that work demands interfere with family demands (WIF) and family demands can also interfere with work demands (FIW).

\section{WIF and FIW}

Work-family interference represents the ability of workplace issues and roles to interfere with family roles and responsibilities of an individual. This dimension of the WFC has also been described as taking work home (Jamaludin, Ibrahim, \& Dagang, 2018; Tsaur \& Yen, 2018; Aslam, Shumiala, Azhar, \& Sadaqat, 2011; Ahmad, 2008), describing the situation where the work duties of an individual are capable of creating some kind of conflict in the family domain as both demands struggle over the finite time and energy at the disposal of the individual, resulting in work-family interference that ultimately results in work-family conflict. In contrast, when there is a disturbance in the work-life of an individual as a result of fulfilling family demands, there is a creation of Family-Work Interference (FIW) (Frone, Russell, \& Cooper, 2000). This emanates from home issues including child and or elderly care issues and the time demanded by family roles just to outline a few (Aslam, Shumiala, Azhar, \& Sadaqat, 2011).

\section{Job Satisfaction}

Locke (1976), classically defines the concept of job satisfaction as a pleasurable or positive emotional state resulting from the appraisal of one's job or job experiences (Locke, 1976). Robbin (2015) also views job satisfaction as the accumulation of feelings (both positive and negative) that an employee ascribes to his or her job. Afzal and Farooqi, (2014) posit that contemporary-day managers find the handling of job satisfaction (JS), a challenging and multifaceted area when because job satisfaction greatly impacts on the motivation of employees, affecting productivity as well as the performance of every service-oriented organization (Aziri, 2011). Therefore, job satisfaction of a hotel employee is essential for the delivery of quality service and the survival of the organization in this ever-competitive industry. Especially in the hotel industry, where employees are required to work during odd hours as well as holidays.

\section{Work-Family Conflict and Job Satisfaction}

Mensah, Amissah and Nsaful (2018) studied how gender moderates the relationships between work-family, job and family satisfaction among junior staff of universities in Ghana. They concluded that WFC negatively impacts job satisfaction. Similarly, Dartey-Baah (2015) affirmed that WFC negatively affects the job satisfaction of corporate managers. Also, studies show that the experience of WFC among corporate leaders affects their job satisfaction negatively (Dartey-Baah, 2015; Mensah et al., 2018). Namasivayam and Mount's (2004) study conducted in Pennsylvania in seven hotels hypothesized an inverse WFC - job satisfaction relationship. The study found out that the greater the work-family interference 
experienced by an individual, the lower the job satisfaction. In the case of family-work interference, it was found that conflicts negatively relate to job satisfaction. In addition, studies by Afzal and Farooqi (2014) and Mensah et al. (2018) depict a negative effect of FIW on job satisfaction. Segbenya, Peniana and Aggrey (2018) also examined the effects of worklife balance on the level of satisfaction with the job of employees of educational institutions. With a total of 140 respondents, it was found that work-life conflict has a moderate negative influence on job satisfaction.

Anafarta (2011) studied, the bi-direction of work-family conflict using structural equation modelling (SEM) to analyze responses from 226 respondents in Turkey. It was found that WIF affects job satisfaction but FIW does not affect job satisfaction. The study revealed a reciprocal relationship between the bidirectional conflicts of WFC. Also, the experience of WFC was noted to have a significant influence on one's job satisfaction while family-work conflict did not have such influence. Job satisfaction has therefore been attributed to lower WFC in such relationships (Chen, Brown, Bowers, \& Chang, 2015; Madhavi, 2015). We, therefore, hypothesize that:

\section{H1: WFC negatively influences hotel employee Job}

\section{Satisfaction}

H2: WIF negatively influences hotel employee Job Satisfaction.

H3: FIW negatively influences hotel employee Job Satisfaction.

\section{Life Satisfaction}

To better understand an individual, Life Satisfaction (LS) plays a major role where the pathway and belief about one's own life resulting in being happy are given a closer look (Lippman, Guzman, \& Moore, 2012). Life satisfaction is the mental constituent of subjective well-being. With this, an individual compares the perception of living standards and living conditions, thus appraising life (Çeçen, 2007). This means that life satisfaction is a very subjective phenomenon. Further evidence from the literature shows that life satisfaction is a vital segment of a happy and decent quality life. It is connected to joy, happiness, essentialness, good faith, enthusiasm, and self-actualization. Again, Karimi, (2008) said LS is the ability of a person to progress confidently in life and is content with his/her life.

\section{Work-Family Conflict and Life Satisfaction}

When role demand conflict arises, detrimental effects are observed in life satisfaction (Afzal \& Farooqi, 2014). However, early studies have suggested that the relationship between life satisfaction and WFC is not fully explained as mixed and differential findings have been realized across studies (Allen et al., 2000). This points to undetected potential moderator variables that may be left unexplained. To Neto, Chambel and Carvalho (2018), there is an inverse association when it comes to WFC and the satisfaction derived from one's life. In the sense that the interference caused by work demands in the family (WIF), and that of family demands in work (FIW) have an inverse influence on job and life satisfaction. Neto et al's (2018) study involving 267 hotel managers in the southern and north-eastern areas of the United States indicated that WIF has a negative correlation with life satisfaction. Also, FIW was found to be inversely correlated with life satisfaction. Thus, the increase in inter-role conflict among hospitality professionals results in a decrease in the level of life satisfaction. Further, the workload of an individual positively predicts the occurrence of WFC in daily life. Using a hierarchical linear model, Goh, Ilies, and Wilson (2015) found that the differences in daily workload influence life satisfaction because it creates work-family conflict which tend to influence the life 
satisfaction of an employee in the hospitality industry negatively. In view of this, we hypothesize that:

\section{H4: WFC and LS have an inverse effect on hotel} employees.

H5: WIF and LS have an inverse effect on hotel employees.

H6: FIW and LS have an inverse effect on hotel employees.

\section{Gender and Work-Family Conflict}

According to gender perspective theory, the gender of an employee can influence his or her behaviour in both domains. This comes as a result of the different responsibilities of men, and that of women in work and family domains. Culture, however, plays a crucial role in ascribing responsibilities in relation to gender disparities. Traditionally, in most parts of Africa, females have more responsibilities related to the family domain (e.g. cooking, cleaning, shopping, preparing meals and caregiving). On the other hand, male responsibilities and demands are related to the work domain. A male's role as the breadwinner and wageearner for the family has long been asserted as dominant (Keene \& Quadagno, 2004). According to this theory, employees experience work-family conflict if they are unable to juggle their responsibilities successfully (Duxbury \& Higgins, 1991).

Interesting gender disparities have been identified over the years in gender studies (Dashper, 2019). Erdamar and Demirel (2016) found females to have higher levels of satisfaction in life as compared to males. Specifically, females suffer more from WIF while males, suffer more from FIW, although the difference was found not to be significant. However, other studies have shown that females experience more conflicts than males. Therefore, work-family conflict is said to be more common than family-work conflict (Anafarta, 2011; Geurts, et al., 2005; Kinnunen, Geurts, \& Mauno, 2004; Özmete \& Eker, 2012). Also, Beek and Bloemberg (2012) studied 417 respondents made up of 244 men and 173 women. Using multiple regression analysis, they revealed negligible differences, with respect to gender and the experience of work-family conflict. Family-to-work conflict can result in some form of anxiety and depression among employed males than females. However, females experience a greater level of anxiety than males with respect to family-workconflict. Conflict and emotional or mental distress are usually strongly evident amongst women having routine jobs and men with harmful work environments though the negative effects of family-to-work conflict are felt by males and females alike. Similarly, Duxbury and Higgins (2003) observed a difference in the degree of work-family conflict experienced by males and females. Ahmad, Ngah, and Baba (2009) posit that work-family conflict significantly affects single mother employees' job satisfaction negatively, buttressing what $\mathrm{Lu}$, Kao, Chang, $\mathrm{Wu}$, and Cooper found in their 2008 study. based on this, we test the moderating effect of gender on WFC-job satisfaction relationship and WFC - employees' life satisfaction relationship.

H7: Gender moderates the WFC-JS relationship.

H8: Gender moderates the WIF-JS relationship.

H9: Gender moderates the FIW-JS relationship. 


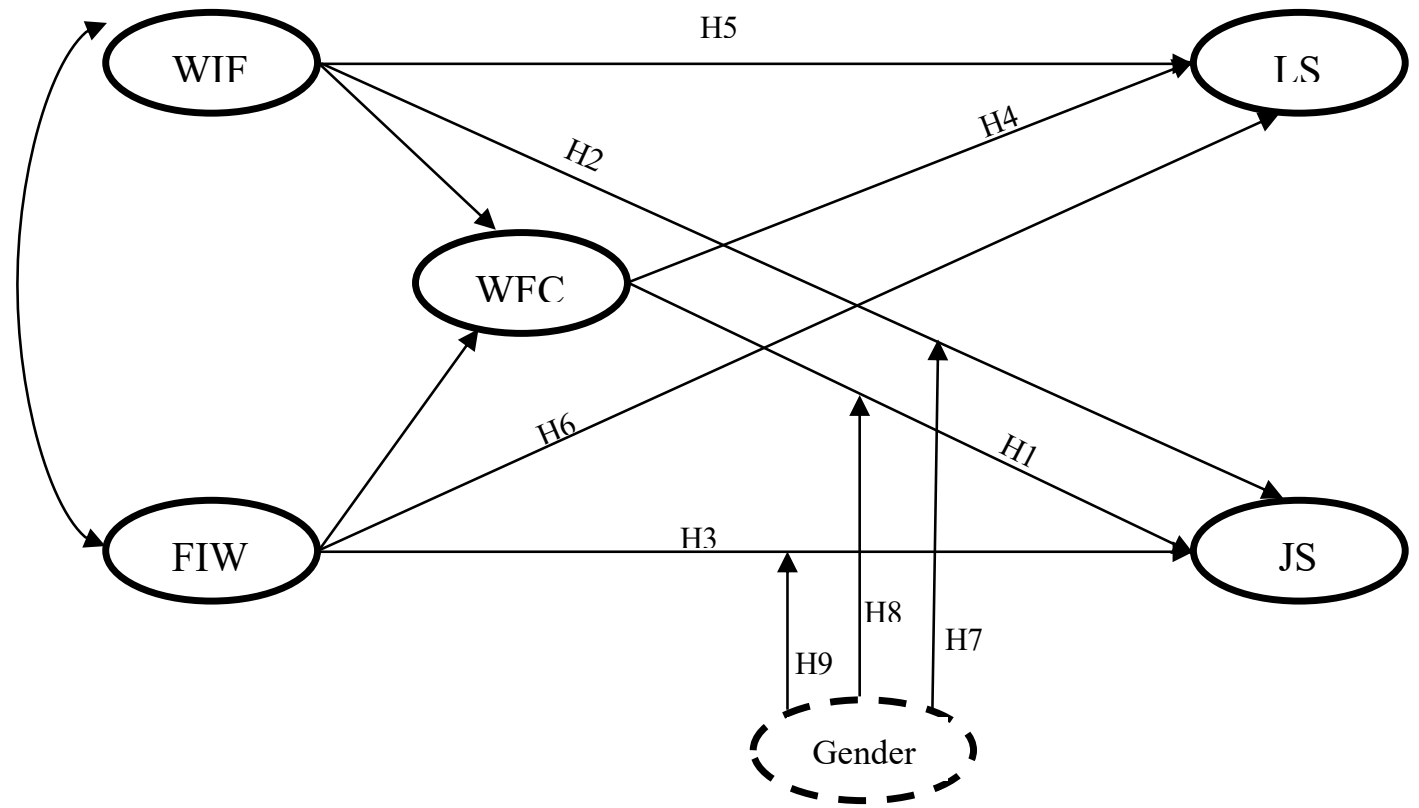

Figure 1: Hypothesized relationships between WIF, FIW, WFC, JS and LS

\section{METHODS}

\section{Participants and Procedure}

The study adopted the cross-sectional design to collect survey data from employees in all the sixteen 3-5-star hotels (two 5-star, six 4-star and eight 3 -star) in the Accra Metropolis of Ghana. A multistage sampling technique was employed in this study. Firstly, we contacted all the Human resource managers of the hotels for permission to conduct our study in their outfits and also to obtain the total number of employees. But 13 voluntarily agreed to participate in the study. The number of employees from the 13 hotels were 1748 ( 5 -star=396; 4-star $=742$; 3 -star=610). Using Fisher et al. (1998) formula to sample from a population of 1748 , we obtained a sample size of 384 . Then, a proportional allocation was assigned to each hotel category. Finally, the convenience sampling technique was used to select employees at the workplace due to the irregular and unpredicted working hours as well as shift system (Amissah, Gamor Deri \& Amissah, 2016; Gamor, Amissah, \& Boakye, 2014). Finally, employees were individually approached at break time during working hours at their hotels. After seeking their consent, the purpose of the study was shared with the respondents. They were requested to fill out the self-administered questionnaires Some questionnaires were misplaced while others were not completely filled so the researcher had to discard them. In total, approximately 400 employees were approached, 302 were returned and 286 were usable (i.e., 60 from 5-star, 115 from 4-star and 111 from 3-star) for analysis (response rate of $72 \%)$.

\section{Measures}

To measure WFC, the study adopted the tenitems scale by Netemeyer, Boles, and McMurrian (1996). This ten-item scale is made up of five WIFrelated items and five FIW-related items. The scale was measured using a five-point Likert scale (i.e., Strongly Disagree to Strongly Agree). Also, on a 5point Likert scale ranging from strongly disagree to strongly agree, job satisfaction was measured on a 6item scale adapted from the Minnesota Job Satisfaction Questionnaire (MSQ) (Weiss, Dawis, England, \& Lofquist, 1967), These scales have been 
used by researchers like Afzal and Farooqi (2014), Rathi and Barath (2013), and Turliuc and Buliga (2014). Satisfaction with Life was measured with the 5-item life satisfaction scale by Pavot and Diener, 1993. Items such as "in most ways, my life is close to my ideal", "the conditions of my life are excellent", "I am satisfied with my life", and "if I could live my life over, I would change almost nothing" were measured on a five-point Likert scale. All the scales and subscales had the satisfactory Cronbach's alpha reliabilities ranging from $0.82-0.90$ and data were normally distributed.

\section{Data Analysis}

Data retrieved from the survey were analyzed with SPSS (version 22.0). Analyses were done by employing correlation and exploratory factor analysis (EFA), together with confirmatory factor analysis (CFA) and Structural equation modelling (SEM) using AMOS (version 22.0). With $\mathrm{Hu}$ and Bentler's (1998) two-index presentation strategy for goodnessof-fit statistics, goodness-of-fit index (GFI), root mean square residual (SRMR), parsimony comparative fit index (PCFI), Tucker-Lewis index (TLI), Root Mean Square Error Of Approximation (RMSEA), as well as the comparative fit index (CFI), and the chi-square statistic were used to assess the adequacy of the measurement and the fit of structural models. Fit- indices values are between 0 and 1, with values closer to 1 indicating that each of the model fit indicators was within the recommended thresholds proposed in the literature for a good fitting model.

\section{RESULTS}

\section{Sample Characteristics}

The sample is made up of a little over half (50.2\%) females. About half (50.5\%) were between the age cohort of $21-30$ years, almost $58 \%$ of them were unmarried, and $38 \%$ had diploma qualifications. Furthermore, the majority $(86.0 \%)$ professed the
Christian faith, with $33.5 \%$ of them earning monthly salaries worth more than GHф1000.00 (US\$ 196.00). Most of the respondents (66\%) were working in backof-the-house.

\section{Confirmatory Factor Analysis (CFA)}

Twenty-one (21) items whose reliability and validity are confirmed in the literature were used for measuring WIF, WFC, FIW, JS and LS. Therefore, the study proceeded to do A CFA for the measurement items because these items have been tested over the years and thus there was no need to re-explore them using EFA/PCA. The conceptual model presented in this study had WIF and FIW as exogenous variables while WFC, JS and LS being endogenous variables were further analyzed with the Confirmatory Factor Analysis (CFA). Factor loadings $(\beta)$ showed strong loadings above the recommended level of 0.6 (Table 1), thereby fulfilling the convergent validity requirements of the items used (Agyeiwaa, Otoo, Suntikul \& Huang, 2018; Kim, Woo \& Uysal, 2015). Further indicators such as the critical ratio (C.R.) also referred to as the standard normal distribution (Teo, Tsai \& Yang, 2013) revealed that when variables have their C. R. $>1.96$ for $\beta$, there is a strong indication that the variable path is significant at the 0.05 level (the estimated path variable or parameter is significant). The squared multiple correlations (SMC) for the constructs also revealed that the percent of variance explained by the predictor variable was high (with the least being 0.51 and the highest 0.88 ), signifying that the indicator/latent variables were reliable in measuring the construct.

As indicated in Table 2, the multidimensionality of WIF, FIW, WFC, JS and LS were also assessed and confirmed by the model fit indices including $\left(\chi^{2}=103\right.$; $\mathrm{df}=55 ; P=0.000 ; \mathrm{RMR}=0.048 ; \mathrm{GFI}=0.943 ; \mathrm{NFI}$ $=0.950$; and $\mathrm{CFI}=0.976)$ indicating that the proposed model and the measurements used were adequate and 
fit the data well (Blunch, 2008). The constructs have high composite reliability coefficients (CR) indicating the reliability (internal consistency) of the constructs (Table 3 ) as the threshold of 0.6 was exceeded. The amount of variance captured by each construct vis-àvis its level of measurement error (AVE) was adequate, that is, AVE $>0.5$ (Alarcon \& Sanchez, 2015), also signifying the convergent validity of the constructs. In evaluating the discriminant validity of the model, the indicator variables were initially analyzed to ensure there was no cross-loading (Hair, Ringle \& Sarstedt, 2011). Furthermore, the square root of the AVE which is a discriminant validity indicator signified that there was a discriminant validity since no construct had high correlation than the square root of the AVE, suggesting that the construct shared high variance with its items as compared to other constructs.

Table 1: Confirmatory Factor Analysis Results

\begin{tabular}{|c|c|c|c|c|}
\hline $\begin{array}{l}\text { Manifest } \\
\text { variables }\end{array}$ & Mean & $\begin{array}{c}\text { Standardized factor } \\
\text { loading } \\
B\end{array}$ & $\begin{array}{c}\text { Composite } \\
\text { Reliability (CR) }\end{array}$ & $\begin{array}{c}\text { Average } \\
\text { Variance } \\
\text { Extracted } \\
\text { (AVE) }\end{array}$ \\
\hline WIF 1 & 2.99 & 0.81 & 0.89 & 0.65 \\
\hline WIF 2 & & 0.83 & & \\
\hline WIF 3 & & 0.76 & & \\
\hline WFC 1 & 2.95 & 0.82 & 0.90 & 0.75 \\
\hline WFC 2 & & 0.90 & & \\
\hline WFC 3 & & 0.87 & & \\
\hline FIW 1 & 2.69 & 0.81 & 0.88 & 0.70 \\
\hline FIW 2 & & 0.88 & & \\
\hline FIW 3 & & 0.81 & & \\
\hline JS 1 & 2.41 & 0.93 & 0.84 & 0.70 \\
\hline JS 3 & & 0.72 & & \\
\hline LS 1 & 3.80 & 0.86 & 0.82 & 0.75 \\
\hline LS 2 & & 0.89 & & \\
\hline
\end{tabular}


Table 2: Goodness-of-Fit Measures

\begin{tabular}{|c|c|c|c|c|c|c|c|c|c|c|c|}
\hline Stage & $\begin{array}{c}\text { Ch- } \\
\text { square } \\
\text { (df) }\end{array}$ & $\begin{array}{c}\text { p- } \\
\text { value }\end{array}$ & RMSEA & RMR & GFI & AGFI & NFI & RFI & IFI & TLI & CFI \\
\hline CFA & $103(55)$ & 0.000 & 0.057 & 0.048 & 0.943 & 0.906 & 0.950 & 0.929 & 0.976 & 0.965 & 0.976 \\
\hline SEM & & & & & & & & & & & \\
\hline
\end{tabular}

CFA (confirmatory factor analysis); RMSEA (root mean square error of approximation); RMR (root mean square residual); GFI (goodness-of-fit); AGFI (adjusted goodness-of-fit); NFI (normed fit index); RFI (relative fit index); IFI (incremental fit index); TLI (tucker-lewis index); CFI (comparative fit index)

Table 3: Composite Reliability, Discriminant and Convergent Validity, Inter-Construct Correlation and Square Root of AVE

\begin{tabular}{lccccccc}
\hline & CR & AVE & WIF & WFC & FIW & JS & LS \\
\hline WIF & 0.81 & 0.64 & $(0.80)$ & & & & \\
WFC & 0.87 & 0.74 & 0.64 & $(0.86)$ & & & \\
FIW & 0.84 & 0.69 & 0.53 & 0.55 & $(0.83)$ & & \\
JS & 0.84 & 0.69 & -0.29 & -0.26 & -0.16 & $(0.83)$ & \\
LS & 0.88 & 0.76 & -0.26 & -0.28 & -0.09 & 0.50 & $(0.87)$ \\
\hline
\end{tabular}

Composite Reliability (CR); Average Variance Extracted (AVE); Value in parenthesis is the square root of the AVE of the construct

\section{Hypothesis Testing of Paths Using Structural Equation Models}

Table 4 and Figure 2 show the path analysis that was used to evaluate proposed associations among variables within the model. The results indicated a five out of the nine direct hypothesised relationships were significant as indicated by their coefficients and $p$ values. WIF was found to have a significant influence on WFC $(\beta=0.48 ; P=0.000)$ and FIW also influenced significantly with WFC $(\beta=$ $0.29 ; P=0.000)$, indicating that an increase in either WIF or FIW would lead to WFC. The results also indicate FIW and WFC did not influence JS $\left(\mathrm{H}_{1}\right.$ and $\mathrm{H}_{3}$ ). However, WIF had a significant inverse correlation with JS $\left(\beta=-0.21 ; P=0.032 ;\left[\mathrm{H}_{2}\right]\right)$, thus, a unit increase in WIF would have a negative influence on JS. Similar results were attained in respect of $\mathrm{H}_{4}$, in which WFC had a significant negative effect with LS $(\beta=-0.18 ; P=0.049)$. Consequently, when workfamily conflict is evident, there is a likelihood of the person not being satisfied in life. However, individually, WIF and FIW had no bearing on LS ( $\mathrm{H}_{5}$ and $\mathrm{H}_{6}$ ).

The study also revealed that when there is evidence of JS, the resultant effect would be LS $(\beta=$ $0.44 ; p=0.000)$. Conceptually, the entire amount of variance that WIF and FIW and its consequent effect that WFC explains in LS is explained through JS. In the setting of employees within the hospitality industry and the service industry at large, the results imply that once there is evidence of work and family inter-role conflict, the resultant effect is work-family conflict. When this occurs, employees job satisfaction is affected and by extension, their life satisfaction. 
Table 4: Path Coefficient of the Structural Equation Model

\begin{tabular}{lccclc}
\hline Hypothesis & SRW & S.E. & C.R & $P$ & $\begin{array}{c}\text { Supported or not } \\
\text { supported }\end{array}$ \\
\hline $\mathrm{H} 1 \mathrm{WFC} \longrightarrow$ JS & -0.14 & 0.09 & -1.48 & 0.137 & Not Supported \\
$\mathrm{H} 2 \mathrm{WIF} \longrightarrow$ JS & -0.21 & 0.10 & -2.14 & $0.032^{*}$ & Supported \\
$\mathrm{H} 3 \mathrm{FIW} \longrightarrow$ JS & 0.36 & 0.08 & 0.41 & 0.678 & Not Supported \\
$\mathrm{H} 4 \mathrm{~W} \mathrm{WFC} \longrightarrow$ LS & -0.18 & 0.08 & -1.96 & $0.049^{*}$ & Supported \\
$\mathrm{H} 5 \mathrm{WIF} \longrightarrow$ LS & -0.07 & 0.09 & -0.82 & 0.409 & Not Supported \\
$\mathrm{H} 6: \mathrm{FIW} \longrightarrow$ LS & 0.11 & 0.08 & 1.45 & 0.147 & Not Supported \\
\hline
\end{tabular}

Standardized regression weights (SRW); Standard error (SE).

**Significant at $p<0.010 ; * p<0.050$

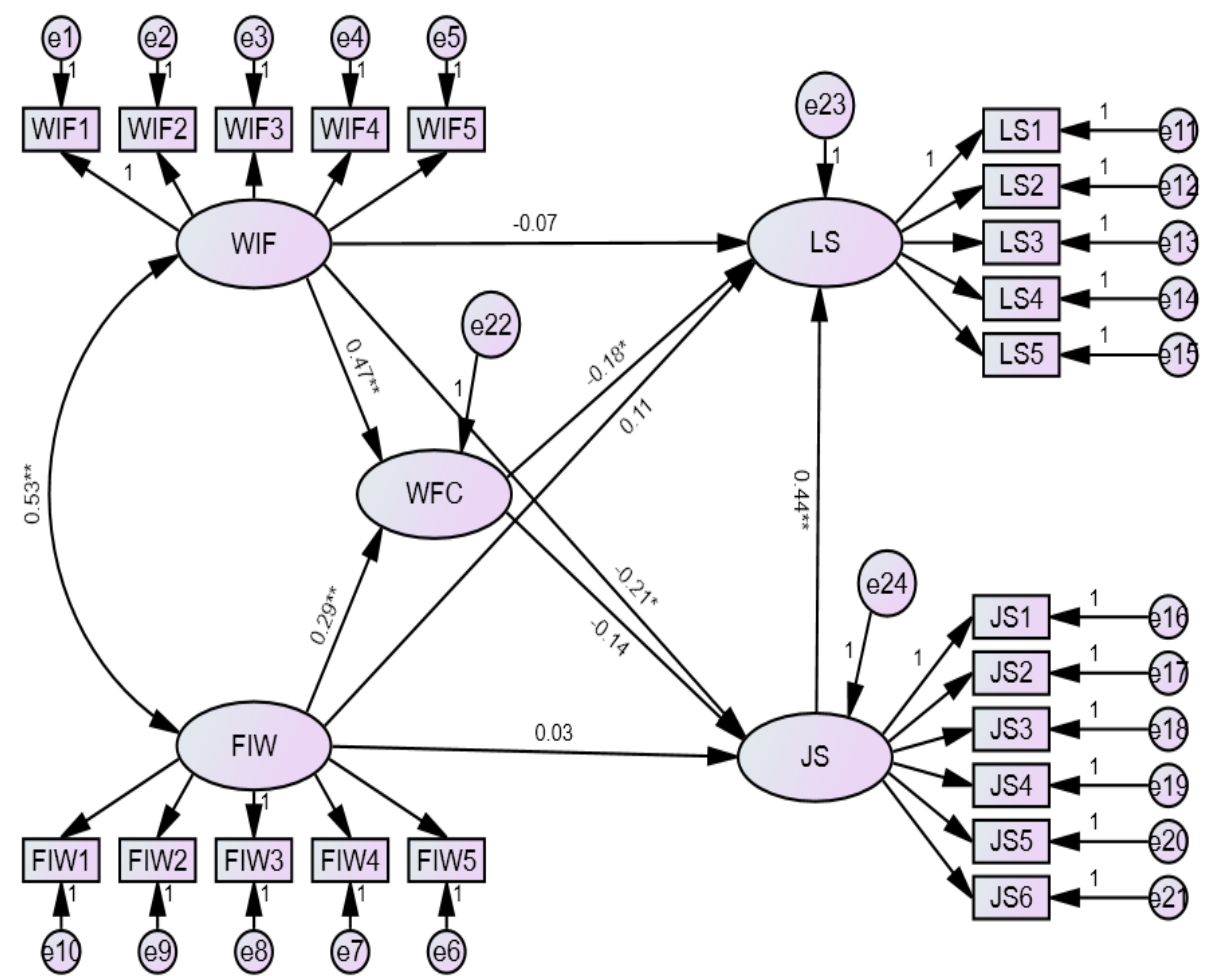

Figure 2: A Structural Equation Model of WIF, FIW, WFC, JS and LS

\section{Multi-Group Invariance Test Across Gender}

Table 5 and 6 present the various dimensions of the hypothesised paths which were assessed across gender through a multi-group invariance test. The model fit indices suggest that there was no significant chisquare difference between constrained and unconstrained models for gender $\left(\mathrm{C} \chi^{2}{ }_{17}=25.40 ; p=\right.$ 0.086). This gives an indication that the model is invariant across the gender characteristics of the respondents. The results (Table 8) indicate that path between WIF and WFC was positively significant for males $(\beta=0.58 ; P<0.010)$ and females $(\beta=0.45 ; p<$ 0.010 ) likewise, a positively significant relationship was identified between FIW and WFC, (male: $\beta=$ $0.20 ; p<0.050$; female: $\beta=0.42 ; p<0.010)$. There was a negatively significant path between WIF and JS for males $(\beta=-0.26 ; p<0.050)$ whereas the path for females was negative but not a significant one $(\beta=$ - 
$0.15 ; p>0.050)$. The male workers also recorded positively significant relationship between FIW and their LS $(\beta=0.29 ; p<0.010)$, but a negatively significant relationship between WFC and LS $(\beta=$ -
$0.42 ; p<0.010)$. The female workers, in contrast, had a positively significant correlation as regards JS and LS path $(\beta=0.48 ; p<0.010)$.

Table 5: Model Fit Indices for Multi-Group Invariances Tests

\begin{tabular}{|c|c|c|c|c|c|c|c|c|c|c|c|c|c|}
\hline $\begin{array}{l}\text { Socio- } \\
\text { demograp } \\
\text { hic } \\
\text { Variable }\end{array}$ & Model & $\chi^{2}$ & $\mathrm{df}$ & $\mathrm{C} \chi^{2}$ & $\begin{array}{l}\mathrm{C} \\
\mathrm{df}\end{array}$ & $p$ & $\begin{array}{c}\text { RMSE } \\
\text { A }\end{array}$ & GFI & NFI & RFI & IFI & TLI & CFI \\
\hline \multirow[t]{4}{*}{ Sex } & Unconstrai & 152.7 & 11 & 25.4 & 1 & 0.08 & 0.042 & 0.91 & 0.93 & 0.90 & 0.98 & 0.97 & 0.98 \\
\hline & ned & 0 & 0 & 0 & 7 & 6 & & 3 & 6 & 9 & 1 & 3 & 1 \\
\hline & Constrained & 178.1 & 12 & & & & 0.043 & 0.89 & 0.92 & 0.90 & 0.97 & 0.97 & 0.97 \\
\hline & & 0 & 7 & & & & & 6 & 6 & 8 & 7 & 2 & 7 \\
\hline Marital & Unconstrai & 182.0 & 11 & 39.3 & 1 & 0.00 & 0.055 & 0.89 & 0.92 & 0.89 & 0.96 & 0.95 & 0.96 \\
\hline \multirow[t]{3}{*}{ Status } & ned & 2 & 0 & 9 & 7 & 2 & & 6 & 4 & 3 & 9 & 5 & 8 \\
\hline & Constrained & 221.4 & 12 & & & & 0.058 & 0.87 & 0.90 & 0.88 & 0.95 & 0.94 & 0.95 \\
\hline & & 0 & 7 & & & & & 5 & 8 & 7 & 9 & 9 & 8 \\
\hline Departme & Unconstrai & 173.3 & 11 & 45.8 & 1 & 0.00 & 0.051 & 0.89 & 0.92 & 0.89 & 0.97 & 0.96 & 0.97 \\
\hline \multirow[t]{3}{*}{$\mathrm{nt}$} & ned & 1 & 0 & 3 & 7 & 0 & & 4 & 9 & 9 & 3 & 0 & 2 \\
\hline & Constrained & 219.1 & 12 & & & & 0.100 & 0.82 & 0.89 & 0.87 & 0.93 & 0.92 & 0.93 \\
\hline & & 4 & 7 & & & & & 7 & 8 & 5 & 8 & 3 & 8 \\
\hline
\end{tabular}

**Significant at $p<0.010 ; *$ Significant at $p<0.050$

Table 6: Multi-Variance Tests for Gender $\left(\mathrm{H}_{7}, \mathrm{H}_{8}\right.$ and $\left.\mathrm{H}_{9}\right)$

\begin{tabular}{lrrrc}
\hline & \multicolumn{4}{c}{ Gender } \\
\cline { 2 - 5 } & \multicolumn{2}{c}{ Male } & \multicolumn{2}{c}{ Female } \\
\cline { 2 - 5 } & $\beta$ & $P$ & $\beta$ & $P$ \\
\hline WIF $\longrightarrow$ WFC & 0.58 & $0.000^{* *}$ & 0.45 & $0.000^{* *}$ \\
FIW $\longrightarrow$ WFC & 0.20 & $0.029^{*}$ & 0.42 & $0.000^{* *}$ \\
FIW $\longrightarrow$ JS & 0.09 & 0.234 & 0.10 & 0.519 \\
WFC $\longrightarrow$ JS & -0.08 & 0.419 & -0.27 & 0.117 \\
WIF $\longrightarrow$ JS & -0.26 & $0.010^{*}$ & -0.15 & 0.365 \\
WIF $\longrightarrow$ LS & -0.13 & 0.345 & -0.02 & 0.870 \\
FIW & 0.29 & $0.009^{* *}$ & 0.12 & 0.395 \\
WFC LS & -0.42 & $0.004^{* *}$ & -0.10 & 0.519 \\
JS & 0.20 & 0.178 & 0.48 & $0.000^{* *}$
\end{tabular}

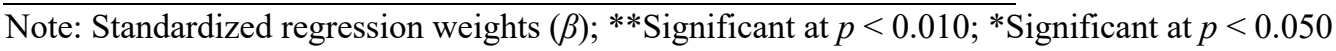

\section{DISCUSSION AND IMPLICATIONS}

This study examined how work-family conflict (i.e. Work-to-family, and the family-to-work) spillover on job and life satisfaction of hotel employees. We found that WIF and FIW significantly influenced WFC. This finding implies that individuals experiencing WIF or FIW will consequently witness WFC which is situated in the domain specificity 
theory of one role domain inhibiting another role domain thus, making it unattainable to meet the demands of the latter role. Thus, buttressing the point that WFC is bi-directional (Frone, Russell, \& Cooper, 2000; Beutell, 2010; Kinnunen, Feldt, Mauno, \& Rantanen, 2010; Aslam, Shumiala, Azhar, \& Sadaqat, 2011; Allen, Johnson, Kiburz, \& Shockley, 2013; Rathi \& Barath, 2013; Qiu \& Fan, 2015; Jamaludin, Ibrahim, \& Dagang, 2018; Tsaur \& Yen, 2018).

Although there are varied findings regarding the relationships existing between WFC, and employees' job satisfaction, our study suggests that work-family conflict is not significantly associated with job satisfaction. This is in line with results from similar research works (Mensah et al., 2018; Segbena et al., 2018; Chen et al., 2015; Madhavi, 2015; DarteyBaah, 2015) that WFC has no significant consequence on employees' job satisfaction. This suggests that employees experiencing WFC are not necessarily dissatisfied with their jobs. Due to social systems, WFC is an everyday phenomenon in Africa, especially Ghana, where employees have social obligations toward both nuclear and extended families. Therefore, experiencing WFC is not seen as one of the factors contributing to job dissatisfaction. This implies that for hotel managers to boost employees' job satisfaction, work overload, supervisor relations, co-worker relations, pay, work environment and other work conditions must be considered. On the other hand, this finding does not support the assertion that as WFC increases, job satisfaction decreases and positive spillover by Xiao and O'Neill's (2010).

Though WFC as a composite variable, did not predict job satisfaction, our study revealed that only work-to-family conflict influence the satisfaction level of employees' job with FIW not related to job satisfaction. The result partly reinforces Neto et al.'s (2018) findings that an increase in WFC results in decreasing level of satisfaction. The result suggests that the time and energy employees have for their families are sacrificed for work activities. Yet, they are still not satisfied with their jobs as the domain specificity theory explains that role in family inhibits the role in work domain of an employee making it difficult to balance it with demands of the latter role. This implies that over time, employees will be dissatisfied and may be unwilling to sacrifice for their jobs as noted by the spillover effect. Therefore, the efforts an employee will make to fulfil his or her family demands could reduce the mental and emotional appraisal of his or her job, leading to an unfavourable attitude to work, low productivity, and even service sabotage.

Also, work-family conflict is significantly related to life satisfaction. Specifically, we found both WIF and FIW uniquely associated with hotel employees' life satisfaction. In other words, regardless of the measure, WFC is negatively associated with hotel employees' level of life satisfaction. Thus, reinforcing Neto et al.'s (2018) findings that the WIF is negatively correlated with life satisfaction and FIW also negatively correlated with life satisfaction. It also re-echoes Zen et al. (2015) claim that work-family conflict has a negative predictive power on daily life satisfaction. This means that as hotel employees experience increasing incompatible roles and responsibilities, their level of satisfaction with life decrease. Hence, the negative spillover of WFC will result in life dissatisfaction among employees. Experiencing constant low life satisfaction levels could be detrimental to both employees (i.e., having low level of self-worth, physical and mental health problems and eventually suicide) and employers (absenteeism, high medical cost and consequently customer dissatisfaction).

Our study provides a deeper understanding of the extent to which gender moderates the relationships between WIF, WFC, FIW, JS and LS. Overall, gender moderated the relationships that existed among WIF, 
WFC, FIW, JS and LS though at varying levels of significance. Specifically, gender uniquely accounted for variation in the influence of FIW on the WFC such that a positive impact of FIW on WFC was more pronounced. The results suggest that male employees who are work-oriented and emotional have a hard time dealing with the stress more effectively and are unable to reduce the detrimental effect of work and its interference with family, which reduces the employees' job satisfaction. However, findings indicating that FIW positively impacts on job satisfaction of female hotel employees implies that females who are family-oriented can cope with the stress that demands from family bring to the work domain effectively. This may be because of the cultural understanding that females have more familyrelated tasks than males. These findings contradict that of Erdamor and Demirel (2016) that females are more affected by WIF while males are more affected by FIW. The findings are, also, consistent with Duxbury and Higgens' (2003) assertion that there exist differences in male and female experience of WFC. Besides, the negative influence of WIF on employees' job satisfaction is more significant among males when compared to females. This further strengthens the gender perspective theory that the gender of an employee can influence his or her behaviour in both work and family domains.

However, the effect of FIW on LS is positive irrespective of gender, though it is much evident among males than females. Considering the African context of the study, where traditional roles concerning gender roles are predominantly clear in a situation where females are considered as care-givers and males as breadwinners. One would expect that females experience more FIW than men. This finding, however, divulges that the effects of FIW on the satisfaction of one's life are serious. that gender does not seem to restrained or change it although males seem to be more affected even if family demands interfere with their work, a very strong affirmation of the spillover theory. This is, however, in contrast with Neto, Chambel and Carvalho's (2018) study positing that WFC and it forms with life satisfaction of an employee, bringing about the effect such as mental health problems.

\section{CONCLUSION AND RECOMMENDATIONS}

Our findings extend previous studies on hotel employees' work and life outcomes demonstrating that employees play a role in their job satisfaction and their life satisfaction as well. Specifically, we disaggregated WFC and applied the gender perspective theory to conclude that gender moderated the relationship between WIF and job satisfaction. In as much as individuals have trouble managing the demands emanating from incompatible roles, they may have the perception that their organizations are unsupportive and that they will feel less satisfied with their job as adduced by the spillover theory. It must also be noted that WFC, among hotel employees, forms an important risk factor that contributes to their physical and mental health problems (Albrecht, Kecklund \& Leineweber, 2020). Hence, hotel employers should try to overcome both conflicts from work and family in order to ensure that employees are satisfied professionally and personally because a satisfied employee translates to satisfied customers. Employers should offer more flexible schedules, family-friendly policies, professional consultations for adjusting work duties with parenthood responsibilities and motivational packages (Mjoli, 2013; Neault \& Pickerell, 2005).

Considering the fact that human capital is one of the important resources for all hospitality businesses, organizations should be interested in the detrimental effects of WFC on staff. Supervisors and co-workers should also support employees with high levels of WFC by encouraging job sharing and assigning a reasonable workload. Employees should 
also get support from families and friends to enable them to work professionally and productively hence, becoming satisfied to perform well on the job. Particularly, staff should call on close relatives and friends in caring for children, the elderly and other family responsibilities. Also, in married homes, both partners should perform housekeeping duties and commit to family engagements (Allan, Loudoun \& Peetz, 2007). We also conclude that the gender of employees moderates the effects of WFC on job and life satisfaction. Since the study was unable to capture the reasons behind the established relationships, a qualitative study can be conducted to ascertain the reasons for such effects.

\section{Limitations and direction for future research.}

The data was collected by self-reported measures. In future, it is suggested that data could be gathered from multiple sources such as spouses, family, colleagues and supervisors' reports. Some other demographic and organisational factors which could affect the study variables like the department of work, the personality of different individuals, organizational climate and culture could also be considered in future studies. The sample size of this study was small $(\mathrm{N}=286)$ and this has affected the generalizability of the present findings. More so, this study adopted the bidirectional measurement of WFC and we recommend that future studies could consider the multidimensional nature of the construct.

\section{REFERENCES}

Albrecht, S.C., Kecklund, G. \& Leineweber, C. (2020). The mediating effect of work-life interference on the relationship between worktime control and depressive and musculoskeletal symptoms. Scand J Work Environ Health, 46(5), 469-479 doi:10.5271/sjweh.3887
Afzal, S., \& Farooqi, Y. A. (2014). Impact of work family conflict/family-work conflict on job satisfaction and life satisfaction: A case study of a public sector university, Gujranwala Division, Pakistan. International Journal of Multidisciplinary Science and Engineering, 5(8), 31-36.

Ahmad, A. (2008). Job, family and individual factors as predictors of work-family conflict. Journal of Human Resource and Adult Learning, 4(1), 57-65.

Allan C., Loudoun R. and Peetz D. (2007) Influences on work non/work conflict, Journal of Sociology, 43(3), 219-239.

Allen, T. D., Herst, D. E., Bruck, C. S., \& Sutton, M. (2000). Consequences associated with work-tofamily conflict: a review and agenda for future research. Journal of Occupational Health Psychology, 5(2), 278-308.

Amissah, E. F., Gamor, E., Deri, M. N., \& Amissah, A. (2016). Factors influencing employee job satisfaction in Ghana's hotel industry. Journal of Human Resources in Hospitality \& Tourism, 15(2), 166-183.

Anafarta, N. (2011). The relationship between workfamily conflict and job satisfaction: A structural equation modeling (SEM) approach. International Journal of Business and Management, 6(4), 168-177.

Aslam, R., Shumiala, S., Azhar, M., \& Sadaqat, S. (2011). Work-family conflicts: Relationship between work-life conflict and employee retention-A compartive study of public and private sector employees. Interdisciplinary Journal of Research in Business, 1(2), 18-29.

Aziri, B. (2011). JOB satisfaction: A literature review. Management Research \& Practice, 3(4), 7786.

Bakker, A. B., Demerouti, E., \& Dollard, M. F. (2008). How job demands affect partners' 
experience of exhaustion: Integrating workfamily conflict and crossover theory. Journal of Applied Psychology, 93(4), 901-911.

Beek, G. V., \& Bloemberg, M. (2012). Gender Differences in Work-Family Conflict: Fact or Fable. A Comparative Analysis of the Gender Perspective and the Gender Ideology Theory, $1-32$.

Beutell, N. J. (2010). Work schedule, work schedule control and satisfaction in relation to workfamily conflict, work-family synergy, and domain satisfaction. Career Development International, 15(5), 501-518.

Çeçen, A. R. (2007). Üniversite öğrencilerinin cinsiyet ve yaşam doyumu düzeylerine göre sosyal ve duygusal yalnızlık düzeylerinin incelenmesi. Mersin Üniversitesi Ĕ̈itim Fakültesi Dergisi, 3(2), 180-190.

Chen, I. H., Brown, R., Bowers, B. J., \& Chang, W. (2015). Work-to-family conflict as a mediator of the relationship between job satisfaction and turnover intention. Journal of advanced nursing, 71(10), 2350-2363.

Choi, H. J., \& Kim, Y. T. (2012). Work-family conflict, work-family facilitation, and job outcomes in the Korean hotel industry. International Journal of Contemporary Hospitality Management, 24(7), 1011-1028.

Dartey-Baah, K. (2015). Resilient leadership: A transformational-transactional leadership mix. Journal of Global Responsibility, 6(1), 99-112.

Dashper, K. (2019). Mentoring for gender equality: Supporting female leaders in the hospitality industry. International Journal of Hospitality Management, 102397.

Duxbury, L., \& Higgins, C. (1991). Gender differences in work-family conflict. Journal of applied psychology, 76(1), 60-74.

Duxbury, L., \& Higgins, C. (2003). Work-life conflict in Canada in the new millennium: A status report. Toronto: Public Health Agency of Canada.

Erdamar, G., \& Demirel, H. (2016). Job and life satisfaction of teachers and the conflicts they experience at work and at home. Journal of Education and Training Studies, 4(6), 164-175.

Frone, M. R., Russell, M., \& Cooper, M. L. (2000). Work-family conflict and employee psychiatric disorders: The national comorbidity survey. Journal of Applied Psychology, 85(6), 888895.

Gamor, E., Amissah, E. F., \& Boakye, K. A. (2014). Work-family conflict among hotel employees in Sekondi-Takoradi Metropolis, Ghana. Tourism Management Perspectives, 12, 1-8.

Gamor, E., Amissah, E. F., Amissah, A., \& Nartey, E. (2018). Factors of work-family conflict in the hospitality industry in Ghana. Journal of Human Resources in Hospitality \& Tourism, 17(4), 482-501.

Geurts, S. A., Taris, T. W., Kompier, M. A., Dikkers, J. S., Van Hooff, M. L., \& Kinnunen, U. M. (2005). Work-home interaction from a work psychological perspective: Development and validation of a new questionnaire, the SWING. Work \& Stress, 19(4), 319-339.

Goh, Z., Ilies, R., \& Wilson, K. S. (2015). Supportive supervisors improve employees' daily lives: The role supervisors play in the impact of daily workload on life satisfaction via work-family conflict. Journal of Vocational Behavior, 89, 65-73.

Goris, J. R. (2007). Effects of satisfaction with communication on the relationship between individual-job congruence and job performance/satisfaction. Journal of Management Development, 26(8), 737-752.

Greenhaus, J. H., \& Beutell, N. J. (1985). Sources of conflict between work and family roles. Academy of Management Review, 10(1), 76-88. 
Higgins, C. A., Duxbury, L. E., \& Lyons, S. (2007). Reducing work-life conflict: What works? What doesn't? Health Canada.

Jamaludin, N., Ibrahim, R., \& Dagang, M. (2018). Social support as a moderator of the relationship between work family conflict and family satisfaction. Management Science Letters, 8(9), 951-962.

Kahn, R. L., Wolfe, D. M., Quinn, R. P., \& Snoek, J. D. (1964). Organisational Stress: Studies in Role Conflict and ambiguity. New York: John Wiley \& Sons, Inc.

Kalliath, P., Kalliath, T., \& Singh, V. (2011). When work intersects family: A qualitative exploration of the experiences of dual-earner couples in India. South Asian Journal of Management, 18(1), 37-59.

Karimi, L. (2008). Do Female and Male Employees in Iran Experience Similar Work-Family Interference, Job, and Life Satisfaction? Journal of Family Issues, 30(1), 124-142.

Karimi, Q., Jomehri, F., Asadzade, H., \& Sohrabi, F. (2012). Consequences of conflict between work and family among Iranian female teachers. Journal of Basic Applied Science Research, 2(2), 1869-1875.

Keene, R. J., \& Quadagno, J. (2004). Predictors of perceived work-family balance: Gender difference or gender similarity? Sociological Perspectives, 47(1), 1-23.

Kinnunen, U., Feldt, T., Mauno, S., \& Rantanen, J. (2010). Interface between work and family: A longitudinal individual and crossover perspective. Journal of Occupational and Organizational Psychology, 83(1), 119-137.

Kinnunen, U., Geurts, S., \& Mauno, S. (2004). Workto-family conflict and its relationship with satisfaction and well-being: A one-year longitudinal study on gender differences. Work \& Stress, 18(1), 1-22.
Laode, A. A., Nur, N., Taufik, H. M., Sabara, G. T., Rosmawaty, Kartini, \& Mirad. (2017). The influence of work family conflict and work stress on employee performance. International Journal of Management and Applied Science, 3(2), $1-6$.

Lippman, I., Guzman, I., \& Moore, K. A. (2012). Measuring flourishing among youth: findings from the flourishing children positive indicators project. Webinar.

Locke, E. A. (1976). The nature and causes of job satisfaction. Handbook of industrial and organizational psychology. Chicago: RandMc Narlly.

Lu, L., Kao, S. F., Chang, T. T., Wu, H. P., \& Cooper, C. L. (2008). Work/family demands, work flexibility, work/family conflict, and their consequences at work: a national probability sample in Taiwan. International Journal of Stress Management, 15(1), 1-8.

Ma, Y., \& Turel, O. (2019). Information technology use in Chinese firms and work-family conflict: The moderating role of guanxi. Telematics and Informatics, 41, 229-238.

Madhavi, C. (2015). Impact of work family conflict on job and life satisfaction. International Journal on Global Business Management \& Research, 3(2), 35-45.

Mensah, A. O., Amissah, E. F., \& Nsaful, A. A. (2018). Gender as a moderator between workfamily conflict, job and family satisfaction. AFRREV IJAH. An International Journal of Arts and Humanities, 7(3), 1-12.

Morrison, D. A., Mensah, J.V., Kpakpo, G.N.A. \& Asante, C. (2020). Work-family conflict and employee performance in Ghana's banking sector. International Journal of Research GRANTHAALAYAH, 8(9),

113-122. https://doi.org/10.29121/granthaa layah.v8.i9.2020.1120 
Namasivayam, K., \& Mount, D. J. (2004). The relationship of work-family conflicts and family-work conflict to job satisfaction. Journal of Hospitality \& Tourism Research, 28(2), 242-250.

Netemeyer, R. G., McMurrian, R., \& Boles, J. S. (1996). Development and validation of worfamily conflict and family-work conflict scales. Journal of Applied Psychology, 81(4), 400410.

Neto, M., Chambel, M. J., \& Carvalho, V. S. (2018). Work-family life conflict and mental wellbeing. Occupational Medicine, 68(6), 364-369.

Ngah, N., Ahmad, A., \& Baba, M. (2009). The mediating effect of work-family conflict on the relationship between locus of control and job satisfaction. Journal of Social Sciences, 5(4), 348-354.

Nordenmark, M. (2017). The importance of job and family satisfaction for happiness among women and men in different gender regimes. Societies, 8(1), 56-63.

O'Neill, J. W., \& Davis, K. (2011). Work stress and well-being in the hotel industry. International Journal of Hospitality Management, 30(2), 385-390.

Özmete, E., \& Eker, I. (2012). İş-Aile Yaşamı Çatışması ve Roller: Kamu Sektörü Örneğinde Bir Değerlendirme. Çalışma İlişkileri Dergisi, $3(2), 1-23$.

Pavot, W., \& Diener, E. (1993). The affective and cognitive context of self-reported measures of subjective well-being. Social Indicators Research, 28(1), 1-20.

Qiu, L., \& Fan, J. (2015). Family boundary characteristics, work-family conflict and life satisfaction: A moderated mediation model. International Journal of Psychology, 50(5), 336-344.
Rathi, N., \& Barath, M. (2013). Work-family conflict and job and family satisfaction: Moderating effect of social support among police personnel. Equality, Diversity and Inclusion: An International Journal, 32(4), 438-454.

Ru Hsu, Y. (2011). Work-family conflict and job satisfaction in stressful working environments: The moderating roles of perceived supervisor support and internal locus of control. International journal of manpower, 32(2), 233248.

Segbenya, M., \& Dela Ahiatrogah, P. (2018). Appraisal of Managerial Roles of Study Centre Coordinators of College of Distance Education, University of Cape Coast. World Journal of Education, 8(5), 1-16.

Afzal, S., \& Farooqi, Y. A. (2014). Impact of work family conflict/family-work conflict on job satisfaction and life satisfaction: A case study of a public sector university, Gujranwala Division, Pakistan. International Journal of Multidisciplinary Science and Engineering, 5(8), 31-36.

Ahmad, A. (2008). Job, family and individual factors as predictors of work-family conflict. Journal of Human Resource and Adult Learning, 4(1), 57-65.

Allan C., Loudoun R. and Peetz D. (2007) Influences on work non/work conflict, Journal of Sociology, 43(3), 219-239.

Allen, T. D., Herst, D. E., Bruck, C. S., \& Sutton, M. (2000). Consequences associated with work-tofamily conflict: a review and agenda for future research. Journal of Occupational Health Psychology, 5(2), 278-308.

Amissah, E. F., Gamor, E., Deri, M. N., \& Amissah, A. (2016). Factors influencing employee job satisfaction in Ghana's hotel industry. Journal of Human Resources in Hospitality \& Tourism, 15(2), 166-183. 
Anafarta, N. (2011). The relationship between workfamily conflict and job satisfaction: A structural equation modeling (SEM) approach. International Journal of Business and Management, 6(4), 168-177.

Aslam, R., Shumiala, S., Azhar, M., \& Sadaqat, S. (2011). Work-family conflicts: Relationship between work-life conflict and employee retention-A compartive study of public and private sector employees. Interdisciplinary Journal of Research in Business, 1(2), 18-29.

Aziri, B. (2011). JOB satisfaction: A literature review. Management Research \& Practice, 3(4), 7786.

Bakker, A. B., Demerouti, E., \& Dollard, M. F. (2008). How job demands affect partners' experience of exhaustion: Integrating workfamily conflict and crossover theory. Journal of Applied Psychology, 93(4), 901-911.

Beek, G. V., \& Bloemberg, M. (2012). Gender Differences in Work-Family Conflict: Fact or Fable. A Comparative Analysis of the Gender Perspective and the Gender Ideology Theory, 1-32.

Beutell, N. J. (2010). Work schedule, work schedule control and satisfaction in relation to workfamily conflict, work-family synergy, and domain satisfaction. Career Development International, 15(5), 501-518.

Çeçen, A. R. (2007). Üniversite öğrencilerinin cinsiyet ve yaşam doyumu düzeylerine göre sosyal ve duygusal yalnızlık düzeylerinin incelenmesi. Mersin Üniversitesi Ĕgitim Fakültesi Dergisi, 3(2), 180-190.

Chen, I. H., Brown, R., Bowers, B. J., \& Chang, W. (2015). Work-to-family conflict as a mediator of the relationship between job satisfaction and turnover intention. Journal of advanced nursing, 71(10), 2350-2363.
Choi, H. J., \& Kim, Y. T. (2012). Work-family conflict, work-family facilitation, and job outcomes in the Korean hotel industry. International Journal of Contemporary Hospitality Management, 24(7), 1011-1028.

Dartey-Baah, K. (2015). Resilient leadership: A transformational-transactional leadership mix. Journal of Global Responsibility, 6(1), 99-112.

Dashper, K. (2019). Mentoring for gender equality: Supporting female leaders in the hospitality industry. International Journal of Hospitality Management, 102397.

Duxbury, L., \& Higgins, C. (1991). Gender differences in work-family conflict. Journal of applied psychology, 76(1), 60-74.

Duxbury, L., \& Higgins, C. (2003). Work-life conflict in Canada in the new millennium: A status report. Toronto: Public Health Agency of Canada.

Erdamar, G., \& Demirel, H. (2016). Job and life satisfaction of teachers and the conflicts they experience at work and at home. Journal of Education and Training Studies, 4(6), 164-175.

Frone, M. R., Russell, M., \& Cooper, M. L. (2000). Work-family conflict and employee psychiatric disorders: The national comorbidity survey. Journal of Applied Psychology, 85(6), 888895.

Gamor, E., Amissah, E. F., \& Boakye, K. A. (2014). Work-family conflict among hotel employees in Sekondi-Takoradi Metropolis, Ghana. Tourism Management Perspectives, 12, 1-8.

Gamor, E., Amissah, E. F., Amissah, A., \& Nartey, E. (2018). Factors of work-family conflict in the hospitality industry in Ghana. Journal of Human Resources in Hospitality \& Tourism, 17(4), 482-501.

Geurts, S. A., Taris, T. W., Kompier, M. A., Dikkers, J. S., Van Hooff, M. L., \& Kinnunen, U. M. (2005). Work-home interaction from a work 
psychological perspective: Development and validation of a new questionnaire, the SWING. Work \& Stress, 19(4), 319-339.

Goh, Z., Ilies, R., \& Wilson, K. S. (2015). Supportive supervisors improve employees' daily lives: The role supervisors play in the impact of daily workload on life satisfaction via work-family conflict. Journal of Vocational Behavior, 89, $65-73$

Goris, J. R. (2007). Effects of satisfaction with communication on the relationship between individual-job congruence and job performance/satisfaction. Journal of Management Development, 26(8), 737-752.

Greenhaus, J. H., \& Beutell, N. J. (1985). Sources of conflict between work and family roles. Academy of Management Review, 10(1), 76-88.

Higgins, C. A., Duxbury, L. E., \& Lyons, S. (2007). Reducing work-life conflict: What works? What doesn't? Health Canada.

Jamaludin, N., Ibrahim, R., \& Dagang, M. (2018). Social support as a moderator of the relationship between work family conflict and family satisfaction. Management Science Letters, 8(9), 951-962.

Kahn, R. L., Wolfe, D. M., Quinn, R. P., \& Snoek, J. D. (1964). Organisational Stress: Studies in Role Conflict and ambiguity. New York: John Wiley \& Sons, Inc.

Kalliath, P., Kalliath, T., \& Singh, V. (2011). When work intersects family: A qualitative exploration of the experiences of dual-earner couples in India. South Asian Journal of Management, 18(1), 37-59.

Karimi, L. (2008). Do Female and Male Employees in Iran Experience Similar Work-Family Interference, Job, and Life Satisfaction? Journal of Family Issues, 30(1), 124-142.

Karimi, Q., Jomehri, F., Asadzade, H., \& Sohrabi, F. (2012). Consequences of conflict between work and family among Iranian female teachers. Journal of Basic Applied Science Research, 2(2), 1869-1875.

Keene, R. J., \& Quadagno, J. (2004). Predictors of perceived work-family balance: Gender difference or gender similarity? Sociological Perspectives, 47(1), 1-23.

Kinnunen, U., Feldt, T., Mauno, S., \& Rantanen, J. (2010). Interface between work and family: A longitudinal individual and crossover perspective. Journal of Occupational and Organizational Psychology, 83(1), 119-137.

Kinnunen, U., Geurts, S., \& Mauno, S. (2004). Workto-family conflict and its relationship with satisfaction and well-being: A one-year longitudinal study on gender differences. Work \& Stress, 18(1), 1-22.

Laode, A. A., Nur, N., Taufik, H. M., Sabara, G. T., Rosmawaty, Kartini, \& Mirad. (2017). The influence of work family conflict and work stress on employee performance. International Journal of Management and Applied Science, $3(2), 1-6$.

Lippman, I., Guzman, I., \& Moore, K. A. (2012). Measuring flourishing among youth: findings from the flourishing children positive indicators project. Webinar.

Locke, E. A. (1976). The nature and causes of job satisfaction. Handbook of industrial and organizational psychology. Chicago: RandMc Narlly.

Lu, L., Kao, S. F., Chang, T. T., Wu, H. P., \& Cooper, C. L. (2008). Work/family demands, work flexibility, work/family conflict, and their consequences at work: a national probability sample in Taiwan. International Journal of Stress Management, 15(1), 1-8.

Ma, Y., \& Turel, O. (2019). Information technology use in Chinese firms and work-family conflict: 
The moderating role of guanxi. Telematics and Informatics, 41, 229-238.

Madhavi, C. (2015). Impact of work family conflict on job and life satisfaction. International Journal on Global Business Management \& Research, 3(2), 35-45.

Mensah, A. O., Amissah, E. F., \& Nsaful, A. A. (2018). Gender as a moderator between workfamily conflict, job and family satisfaction. AFRREV IJAH. An International Journal of Arts and Humanities, 7(3), 1-12.

Morrison, D. A., Mensah, J.V., Kpakpo, G.N.A. \& Asante, C. (2020). Work-family conflict and employee performance in Ghana's banking sector. International Journal of Research GRANTHAALAYAH, 8(9), 113-122. https://doi.org/10.29121/granthaa layah.v8.i9.2020.1120

Namasivayam, K., \& Mount, D. J. (2004). The relationship of work-family conflicts and family-work conflict to job satisfaction. Journal of Hospitality \& Tourism Research, 28(2), 242-250.

Netemeyer, R. G., McMurrian, R., \& Boles, J. S. (1996). Development and validation of worfamily conflict and family-work conflict scales. Journal of Applied Psychology, 81(4), 400410.

Neto, M., Chambel, M. J., \& Carvalho, V. S. (2018). Work-family life conflict and mental wellbeing. Occupational Medicine, 68(6), 364-369.

Ngah, N., Ahmad, A., \& Baba, M. (2009). The mediating effect of work-family conflict on the relationship between locus of control and job satisfaction. Journal of Social Sciences, 5(4), $348-354$

Nordenmark, M. (2017). The importance of job and family satisfaction for happiness among women and men in different gender regimes. Societies, 8(1), 56-63.
O'Neill, J. W., \& Davis, K. (2011). Work stress and well-being in the hotel industry. International Journal of Hospitality Management, 30(2), 385-390.

Özmete, E., \& Eker, I. (2012). İş-Aile Yaşamı Çatışması ve Roller: Kamu Sektörü Örneğinde Bir Değerlendirme. Çalışma İlişkileri Dergisi, $3(2), 1-23$.

Pavot, W., \& Diener, E. (1993). The affective and cognitive context of self-reported measures of subjective well-being. Social Indicators Research, 28(1), 1-20.

Qiu, L., \& Fan, J. (2015). Family boundary characteristics, work-family conflict and life satisfaction: A moderated mediation model. International Journal of Psychology, 50(5), 336-344.

Rathi, N., \& Barath, M. (2013). Work-family conflict and job and family satisfaction: Moderating effect of social support among police personnel. Equality, Diversity and Inclusion: An International Journal, 32(4), 438-454.

Ru Hsu, Y. (2011). Work-family conflict and job satisfaction in stressful working environments: The moderating roles of perceived supervisor support and internal locus of control. International journal of manpower, 32(2), 233248.

Segbenya, M., \& Dela Ahiatrogah, P. (2018). Appraisal of Managerial Roles of Study Centre Coordinators of College of Distance Education, University of Cape Coast. World Journal of Education, 8(5), 1-16.

Segbenya, M., Peniana, F., \& Aggrey, E. (2018). Effect of Work conflict on employees job satisfaction: The case of college of distance educaion, University of Cape Coast. European Scientific Journal, 14(7), 1857-1881.

Trachtenberg, J. V., Anderson, S. A., \& Sabatelli, R. M. (2009). Work-home conflict and domestic 
violence: A test of a conceptual Model. Journal of Family Violence, 24(7), 471-483.

Tsaur, S. H., \& Yen, C. H. (2018). Work-leisure conflict and its consequences: Do generational differences matter? Tourism Management, 69, $121-131$

Turliuc, M. N., \& Buliga, D. (2014). Work-family conflict and job and family satisfaction. The mediating role of cognitions. Procedia-Social and Behavioral Sciences, 159, 105-109.

Weiss, D. J., Dawis, R. V., England, G. W., \& Lofquist, L. H. (1967). Minnesota studies in vocational rehabilitation. Manual for the Minnesota satisfaction questionnaire, 22, 23-4.
Xiao, Q., \& O'Neill, J. W. (2010). Work-family balance as a potential strategic advantage: A hotel general manager perspective. Journal of Hospitality \& Tourism Research, 34(4), 415439. doi:10.1177/1096348009350645

Yoo, G., \& Lee, S. (2018). It doesn't end there: workplace bullying, work-to-family conflict, and employee well-being in Korea. International journal of environmental research and public health, 15(7), 1548.

Zhang, M., Griffeth, R. W., \& Fried, D. D. (2012). Work-family conflict and individual consequences. Journal of Managerial Psychology, 27(7), 696-713. 